\title{
Blunders of Government Communication: The Political Economy of COVID-19 Communication Policy in Indonesia
}

\author{
Masduki \\ Department of Communication, Universitas Islam Indonesia, Yogyakarta \\ (email: masduki@uii.ac.id)
}

\begin{abstract}
Government officials and politicians have been both a help and hindrance in the public dissemination of information during the COVID-19 pandemic. The intervention of a president and his/her ministries with their political and economic interests is particularly problematic when they employ a tactical approach rather than provide accurate and effective disaster information. This paper utilizes a political-economy approach to analyze the link between COVID-19 communication policies and practices with the interests of politics and market stability in Indonesia. In this paper, the author drills into the extent to which the country's president and ministries manage their political interests in times of global pandemic. The ways they interact with the public during various stages of disaster are crucial because society is severely disrupted, with the government serving as the sole actor. This study uses qualitative methods and all materials are managed from an extensive review of current literature, policy analysis, and field observation. This paper finds that Indonesian government communication during the COVID-19 pandemic period (FebruaryJune 2020) has been dominated by a desire to maintain a strong power of the ruling authority and to secure market stability. Two factors - pro-market communication policies and manufacturedpoliticized COVID-19 data-have occurred. This paper contributes to the literature by focusing on the political and economic approach over the mediated discourses surrounding the pandemic.
\end{abstract}

\section{Keywords:}

COVID-19; political-economy; political security; market stability, Indonesia

\section{Introduction}

The history of epidemics and pandemics has been replete with competing interests. When health and social recovery become political decisions, they may be manipulated and are often energized by primordial politics (for instance, right-wing politicians' calls for policing European countries' national borders following increased non-European migration) (Cherkaoui, 2020). During the ongoing COVID-19 pandemic, political policies in Europe and the US have promoted isolationism and 'closed doors'. Pro-Trump Americans and Euroskeptics are capitalizing on the fear of COVID-19 to impose more barriers and border security, while right-wing populist politicians have argued that COVID-19 shows the need to protect national borders. Cherkaoui (2020) noted, the virus has been portrayed as 'foreign', and as such walls have been built and international flights have been stopped in response.

The 2019 novel coronavirus disease (2019nCoV, more widely known as COVID-19), caused by Severe Acute Respiratory Syndrome Coronavirus 2 (SARS-CoV-2), is a global health emergency of unprecedented proportions. The ongoing loss of life, articulated differently within individual nations, as well as the virus's ability to spread rapidly through communities 
due to asymptomatic carriers, has generated a need for risk-based communication strategies as a political action (Quinn, 2018).

To deal with the global pandemic and its far-reaching political-economic implications, political leaders have sought to persuade the public to voluntarily comply with costly preventive measures (Gerstenfeld, 2020; Sparkes et al., 2019). Governments' issuing of orders to reduce contact between individuals, as well as their communications about the severity with which individuals should treat the rapidly spreading disease and adhere to preventive measures, are particularly influential when dealing with a novel disease for which there is limited information. Where political actors lack credibility and situational awareness, complex and non-health crises often follow (McLean \& Ewar, 2015). A critical analysis of the linkages between government communications (competencies and strategies) and their political-economic agendas is thus crucial, as will be discussed here.

In Indonesia, the government's denial, reluctance, and alarm in responding to the coronavirus crisis between February and May 2020 has led to a series of public controversies. The uncertainty of data regarding COVID-19 fatalities, due to poor database management and conflicting data from top officials and experts, has resulted in uncertainty in action. For instance, the government has officially identified 1,706 COVID-19 cases in Jakarta; however, most Indonesian scientists estimate that the capital has seen 32,000 cases, and thus the government has only published $2.3 \%$ of the actual number of cases (Kompas.com, 2020 April 4). Media observers criticize the lack of transparency in COVID-19 reporting as well as state-funded recovery programs.

On March 10, 2020, the World Health Organization (WHO) formally recommended that Indonesian authorities declare COVID-19 a national emergency, regarding the standard risk communication that had been applied for past pandemics such as the SARS and H1N1 outbreaks (Jakarta Post, 2020 March 14). However, the regime denied this request, citing social, political, and economic reasons. Instead, Jokowi and Minister of Health Terawan Agus Putranto choose to slow the publication of COVID-19 data.

Surveying the political communication of President Joko 'Jokowi' Widodo during the COVID-19 pandemic, the Center for Research, Education, and Publication of Social and Economic Issues (Wijayanto, 2020) found several blunders. This study found that between 1 January and 5 April 2020, the government had made 37 mistaken statements concerning the virus in mainstream media. Take, for instance, Coordinating Minister of the Economy Airlangga Hartarto's joking statement that the virus would not enter Indonesia owing to the country's complicated licensing laws.

On social media, supporters and opponents of the regime have actively turned all issues into partisan squabbles, framing extremely serious discussions about disaster prevention as a shallow and nauseating political spectrum. For instance, social media users have been engaged in a heated debate over whether Indonesia should impose a total or partial lockdown to "flatten the curve" of the infection (Hermawan, 2020). Are these verbal blunders merely technical issues, or are they part of a political and economic scenario to build an image of a strong government facing the global pandemic?

Complex global health risks such as climate change, terrorism, and pandemics (for example, SARS, Ebola \& H1N1) have become important topics in academia. When observing pandemics, communication scholars in Indonesia have frequently employed the theoretical approach of crisis communication and provided practical evaluations; a politicaleconomic approach, as used in many developed economies such as Germany, Singapore, 
Taiwan, and Canada (Dickmann et al., 2014; Hsu et al., 2017; J et al., 2013; Menon \& Goh, 2005; Michelle Driedger et al., 2018; Sparkes et al., 2019; Winseck, 2016), has been lacking. This paper is an effort to link the state's communication strategies with the macropolitical and economic agendas of the regime.

With those backgrounds in mind, this study wants to answer these two research questions: what are Jokowi's communication related-policies to tackling the COVID-19 pandemic? What factors determine communication policies from the politicaleconomic perspective?

This paper is ordered as follows: First, it discusses the conceptual debate regarding the political economy of risk communication. Second, it describes the method used for this study. Third, it explores the main findings of this study concerning several controversial policies and public issues. Fourth, it provides conclusions and recommendations.

\section{The Political Economy of Risk Communication}

The application of the political-economic (PE) approach to communication and media studies was popularized by scholars such as Hardy, (2014); Herman \& Chomsky, (2000); Mosco, (2004). The central argument of the approach is that all communication policies and practices address the political and economic agenda of those in power. The use of the PE approach for this study is relevant in the sense that it does not merely explore the practices of communication, but can also examine the presence of non-public oriented interests through how communications are organized during the crisis. Moreover, the approach does not just map policies, but critically evaluates them as well.

This study precisely uses critical political economy, a critical thought rooted within Marxist traditions with special attention to the use of regulatory capitalism (Levi-Faur, (2009) in tackling the COVID-19 pandemic.
Levi-Faur argues that regulatory processes and outputs shape the operation, manipulation and deployment of political and economic powers. Mosco (2009), meanwhile, surveys a broad range of approaches to political economy and suggests that, when discussing communication policies and practices, the main lines of development are variations on Marxist political economy. In this sense, Marx's class state thesis can be used to mark the capitalistic orientation of political powers' policies (Fuchs \& Mosco, 2016) favoring economic elites over ordinary people.

In the sense that disasters are political events (Olson \& Gawronski, 2010), critical political economy was used in the study to observe risk communication strategies applied by Indonesian authorities during the COVID-19 pandemic. McLean \& Ewar, (2015) argue that dissemination of public information is a political decision involving state authorities as key actors. Political elites not only consider the short-term interest of maintaining social stability but also their political careers. Public statements regarding COVID-19, and communication policies used by President Jokowi, for instance, can be seen as a political action to maintain power until the 2024 election.

German Neo-Marxists, such as Jurgen Habermas in his book The Structural Transformation of the Public Sphere (1962), have concerned themselves with the communications of governments that have been critically eroded by commercial forces. According to Habermas, the public statements delivered by authorities are not neutered, just neglected, manipulated, or squandered.

The crises such as COVID-19 have triggered an extraordinary increase in information flow. The public wants to know what is happening, what needs to be done, and demands that official institutions provide statements that are consistent, open, and accurate; if not, the information vacuum will be filled by 
false information disseminated either out of ignorance or malicious intent (Coombs, 2008). As mentioned by Seneviratne et al., (2010), there is a need for risk communication strategy with a strong communication leadership in every technical statement.

The World Health Organization (WHO) defines risk communication as follows: "the real-time exchange of information, advice and opinions between experts or officials, and people who face a threat (hazard) to their survival, health or economic or social well-being" (Xiang et al., 2017). Risk communication thus has two main components: form and content. Form is the speed, consistency, and openness with which information is conveyed, while content refers to the information conveyed itself (Coombs, 2008). Referring to McLean \& Ewar (2015), communication policy is central and it requires an empathy towards victims, as well as basic economic resources. Referring to the Ministry of Health of the United Kingdom, Menon \& Goh, (2005) identify risk communication as having four principles in which state officials play a key role: undertaking agenda-setting by framing statements in specific contexts (comparison, analogy) and helping people develop life expectancies; providing open case data, accompanied by supporting evidence for each event and action; showing information on actions and results; and treating public anxiety seriously, even when that anxiety is unwarranted.

Campos \& Reich (2019) identified six categories of stakeholders that are likely to influence health communication crises and the subsequent recovery stage: interest group politics, bureaucratic politics, budget politics, leadership politics, beneficiary politics, and external actor politics. For this paper, the author has chosen two aspects: bureaucratic politics and budget politics. The former examines the relationship among different state agencies responsible for health issues such as the COVID-19 pandemic.
Different agencies may attempt to capture political communication policies as a means of protecting and expanding their authority, budget, or general influence (Sparkes et al., 2019). As a result, conflict, negotiation, and compromise can influence actual government policies and actions. It can also push for shifts in the governance of the relationships between those agencies. Budget politics focuses on budget allocation and expenditure mechanisms, as well as their impact on policy implementation. It explicitly acknowledges that resource mobilization and allocation at the national and local levels are inherently political processes. It also explicitly recognizes that the commitment of heads of state determines the political benefits and costs of actions and thereby influences the sustainability of rule.

Government communication is always an interesting object of study due to involved institutions and actors' power to select strategies for managing national crises (Seneviratne et al., 2010). Public and/or government communication consists of related policies, statements delivered regularly to the public, and models of communicative actions, including the format and content of policies that manage communication practices, mandate spokespersons, select media publications, and involve non-authoritative communication leaders such as army officers and social media influencers. Learning from Singapore's experience managing the SARS pandemic in 2004 (Menon \& Goh, 2005), two factors are important: transparency in pandemic data and the involvement of a single and authoritative public communicator in communicating government agendas.

Research into the politics of disaster has taken various approaches; in this paper, the author drills into the extent to which political actors manage their political and economic interests in times of global pandemic. The ways political actors interact with the public during various stages of disaster are crucial because society is severely disrupted, with the 
government serving as the sole actor. Disasters usually become increasingly politicized as impacted citizens move from the emergency response phase through to the recovery and reconstruction (Olson \& Gawronski, 2010). The recovery phase has particularly significant implications for politicians, as it is a time when both victims and the public expect a diligent response from the authorities.

Finally, examining the non-health orientation of public policies, Xiang et al., (2017) details a number of problems with risk communication in a disaster period: (1) political leaders are not transparent; (2) the media are not always the primary sources of awareness about the dangers of disease; (3) crises of scientific evidence presented by authorities in official statements and informative messages such as logistical availability, vaccine safety guarantees (Vaughan \& Tinker, 2009). In this context, the political economy perspective pays close attention to several factors: who controls the information, who owns the data, and how the data is communicated (McChesney, 2012). Data communication is not always neutral and objective.

As of May 20, 2020, Indonesia has reported 19,189 cases, including 4,575 recoveries and
1,242 deaths (Covid19.go.id). During this crisis, Jokowi's risk communication has not been focused on health issues. When the pandemic began in Wuhan, China, Indonesia showed little concern, stating that victims of the virus could recover on their own. Even after President Jokowi announced the first local case of COVID-19 on March the 3, 2020, the information crisis continued (Winanti \& Mas'udi, 2020). The central government reported different data of victims, while various agencies appointed their own 'spokespersons' and used different approaches to dealing with the crisis.

Drawing from the above concepts and raw data from the current study, the research proposition is structured as follows:

The figure above shows areas of politicaleconomic interests in COVID-19 communication policies in Indonesia. They represent two waves of the non-health/non-public interest policy orientation: pro-market COVID-19 through a series of regulatory production and political stability as pre-condition of the market/economic stability during the global crisis. The four sectors above: Communicationrelated Policies of COVID-19, manufactured data dissemination; involvement of social

Figure 1.

Areas of Political Economy in Covid-19 Communication

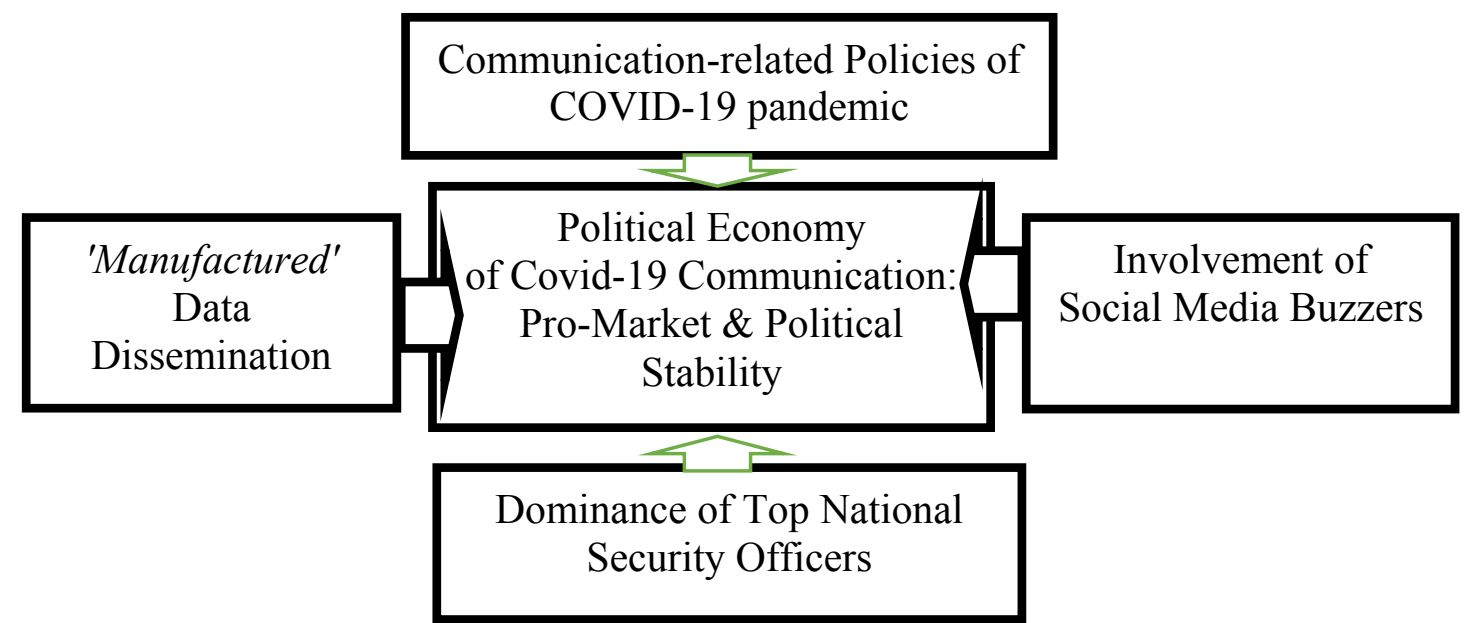

Source: Author, 2020 
media buzzers; and dominance of top national security officers were used as a framework and guide for the author to arrange and organize the findings in the present study.

\section{Methods}

This article is based on a study about how uncertainties in governmental risk communication were not only caused by the incompetence of communicators but also steered by the macro-political economic goals of the ruling government. A qualitative approach (Denzin \& Lincoln, 1994) was chosen since it enabled the examination of the way state communication strategies are created and oriented. The study focuses on several strategies for governmental communication (including COVID-19 related policies, public statements, spokespersons, etc.). Extensive reviews of literary sources, policies, and field observations were conducted to collect study data.

This paper, generally, examines whether the communication strategies employed by Jokowi's political administration were influenced by his political interest to secure strong control and market stability. In doing so, the author conducted several steps of the qualitative research method. In the beginning, a previous study conducted by LP3ES on Indonesian state officials' blunders was used as the initial reference, followed by an analysis of the content of selected statements regarding public issues. Going forward, several controversial policies regarding COVID-19 (i.e. (1) Government Regulation (PP) on LargeScale Social Restrictions, which stipulates that large-scale social restrictions must be approved by the central government before being enacted; (2) Presidential Decree on Public Health Emergency; and (3) Regulation in Lieu of Law (PERPPU) No. 1 of 2020 concerning the stability of the state financial system (BBC, 2020 May 12)) were assessed. The informal observation was conducted to understand the media's exposure of COVID-19 and to see how the political authorities deliver their speeches.

To gain the perspectives of media professionals aboutgovernment communication policies, several senior journalists were interviewed, among them were the Chairman of the Alliance of Indonesian Journalists (AJI) Abdul Manan and the managing editor of Kompas.com, Heru Margianto. A mix of document collection and analysis, field observations, and the interviews ensure both validity and depth of the present study.

The choice of critical PE in this paper as an analytical tool contributes to a current lack of research on the macro level of communication practices driving governments' response to the COVID-19 pandemic. Furthermore, there is a paucity of research into a particular national communication crisis as well as interactions between political/economic narratives and health narratives. Strategic narratives and the pandemic have yet to receive substantive investigation in Indonesia. Since January 2020, robust academic publications have emerged from such medical disciplines as virology, immunology, epidemiology, and bioinformatics. Unfortunately, there has been little to no scholarly work emerging from nonmedical disciplines.

\section{Results}

This section explores the findings of this study about two issues: pro-market communication policies during the COVID-19 pandemic in Indonesia and manufacturing the COVID-19 pandemic data.

\section{Pro-Market Communication Policies}

It is important to note that no formal, specific, and textual COVID-19 communication policy has been produced by President Jokowi. Rather, the policies discussed in the current article are embedded into broader policies on managing the pandemic. All policies are seen as tools of communication and evidence 
of government's concern for the pandemic. During the period of January-June 2020, numerous government policies were issued in response to the COVID-19 pandemic as provided below:

Based on the table above, three policies that had been enacted by May 31, 2020, serve as the focal point of the study, namely: (1) Government Regulation (PP) on Large-Scale Social Restrictions, which stipulates that largescale social restrictions must be approved by the central government before being enacted; (2) Presidential Decree on Public Health Emergency; and (3) Governmental Regulation in Lieu of Law (PERPPU) No. 1 of 2020 concerning the stability of the state financial system (BBC, 2020 May 12). The PERPPU, passed on May 18, 2020, was widely criticized by civil society and challenged in the Constitutional Court for granting state officials the exclusive right to spend money without parliamentary approval.

When the threat of the COVID-19 pandemic was first recognized in January 2020, the Indonesian government's policy seemingly favored promoting economic stability over anticipating health problems.
Some instances include, Jokowi stimulating the tourism industry, allocating funds for influencers, encouraging citizens to travel, etc. The Minister of Health, Terawan Agus Putranto, underestimated the virus by saying the positive cases would recover on their own, and that it was most important to remain fit and to continue to pray (Wijayanto, 2020). When the first cases of COVID-19 were reported in Depok, West Java, on March 2, 2020, President Jokowi began to realize that the situation was more than a mere economic crisis. Only then did he announce the case directly to the public and urge Indonesians to maintain social distance.

In terms of budget, the Ministry of Health has only received a budget allocation of IDR 75 trillion, while a total of IDR 405 trillion has been allocated for restoring the national economy-nearly 20 percent of the 2020 state budget of 2,540 trillion (Rizky, 2020). This stimulus package is focused on community health insurance, social safety net programs for people in need, and incentive packages to ensure the sustainability of small-scale enterprises' economic activities. The IDR 255 trillion in state expenditure for COVID-19

Table 1.

\section{Controversial Policies on the COVID-19 Pandemic}

\begin{tabular}{|c|c|c|}
\hline Policy & Level & Issue \\
\hline $\begin{array}{l}\text { Presidential decree No. } 7 / 2020 \text { on the task force } \\
\text { to accelerate prevention of the Coronavirus } \\
\text { (COVID-19) }\end{array}$ & President & $\begin{array}{l}\text { Governor, Regent, and/or City Mayor as the leader } \\
\text { of the regional task force may create policies with } \\
\text { the approval of the central government. }\end{array}$ \\
\hline $\begin{array}{l}\text { Presidential decree No. } 11 / 2020 \text { on the } \\
\text { declaration of national health emergency during } \\
\text { the COVID-19 pandemic }\end{array}$ & President & $\begin{array}{l}\text { Advancing strict political control by reason of the } \\
\text { COVID- } 19 \text { health crisis }\end{array}$ \\
\hline $\begin{array}{l}\text { Presidential decree No. } 12 / 2020 \text { on the } \\
\text { declaration of national non-natural disaster due } \\
\text { to COVID - } 19\end{array}$ & President & $\begin{array}{l}\text { Advancing strict political control by reason of the } \\
\text { COVID- } 19 \text { health crisis }\end{array}$ \\
\hline $\begin{array}{l}\text { Governmental Regulation in Lieu of Law No. } \\
1 / 2020 \text { on the financial policy to stabilize the } \\
\text { national budget and financial system in coping } \\
\text { with CORONA }\end{array}$ & President & $\begin{array}{l}\text { Showing priority of budget protection by reason } \\
\text { of national economic stability }\end{array}$ \\
\hline $\begin{array}{l}\text { Decree of the Minister of Transportation No. } \\
18 / 2020 \text { on the public transportation management } \\
\text { to address the transmission of the Coronavirus }\end{array}$ & Ministry & $\begin{array}{l}\text { Policy on the use of all public and personal vehicles, } \\
\text { physical distancing, limitation of passengers. } \\
\text { It applies to all types of vehicles incl. logistic } \\
\text { transports. }\end{array}$ \\
\hline
\end{tabular}

Source: compilation of documents 
mitigation has been aimed at three groups. Approximately IDR 75 trillion has been allocated for handling the pandemic, such as by providing medical devices and incentives to medical personnel; a total of IDR 110 trillion has been allocated for social safety nets; and IDR 70.1 trillion has been allocated for business (industry), including general tax subsidies (Rizky, 2020). This indicates that IDR 150 trillion of all expenditures has been allocated to support Small and Medium Enterprises (Usaha Kecil dan Menengah).

\section{'Manufacturing' and Politicizing the Pandemic}

The term 'manufactured' refers to the seminal book Manufacturing Consent: The Political Economy of the Mass Media (1998), written by Edward S. Herman and Noam Chomsky. With this term, the author sees communication practices (i.e. manufacturing victims' identities) as tools for 'manufacturing public perceptions' of the pandemic. During February and June 2020, it was evident when the central government manufactured and politicized pandemic data in several ways; the predominance of military elites in COVID-19 public communication; and the use of social media buzzers.

In delivering statistical data regarding victims, authorities have used many terms that not only classify victims but also present the government as being politically in control of the pandemic. This has included: (1) classifying victims as people under monitoring (orang dalam pemantauan/ODP), patients under monitoring (pasien dalam pemantauan/PDP), and infected persons; (2) the use of the euphemism 'large-scale social restrictions' instead of the popular term in public: 'lockdown'; (3) the distinction between the terms 'homecoming' (pulang kampung) and 'going home' (mudik).

The use of multiple acronyms for identifying victims, can be seen not only as helping citizens become aware of actual conditions and societal positions, but also as a product of manufacturing real data. The government seeks to explain the real situation in the country while maintaining Indonesia's 'normal ranking' (32 of 215 countries) in the global victim distribution - which it had done so successfully as of late May 2020 (Worldometer, 2020).

This study also found the lack of real, transparent data on the pandemic and recent developments. For instance, official government data indicated that 765 people had died of COVID-19 in Indonesia, while the international media association Reuters reported more than 2,200 deaths. Many of these were not recorded as victims of the disease (Reuters, 2020 April 28). The controversial data publication has created a false sense of policy: instead of preparing for recovery, officials have looked for ways to avoid responding. Jokowi has defended his administration's response by noting global scientists' inability to provide definitive predictions of the pandemic.

In collecting official data, the Health Ministry of Indonesia initially insisted on counting only the polymerase chain reaction tests performed by a single facility in Jakarta, ignoring the surge in suspected cases and positive results from the rapid antibody tests conducted by regional authorities. Unconvinced by official figures, Reuters pieced data from cemeteries, medical records, and Jakarta governors' tallies to reveal that more than 2,200 suspected patients have died while awaiting tests. In a press conference, President Jokowi admitted that data was concealed to prevent mass panic (Kompas.com, 2020a March 13), i.e. to ensure political and economic stability. As such, his administration used flawed data to defer critical intervention and delayed the official declaration of a health emergency for several weeks. Finally, on April 24, 2020, the government banned most commercial travel in a bid to prevent the annual Eid exodus of 20 million people; however, an estimated 1.6 million people had already made the journey. 


\section{Discussion}

Based on intensive reviews of several policies throughout the period of JanuaryJune 2020, the study found that Jokowi's administration prioritized two factors: the stability of political power which leads to the protection of business in support of his political authority. Applying the concepts of critical political economy, Jokowi set his communication of political events similar to that of his election period in which he tried to keep a good image through a series of risk communication practices. Moreover, he mobilized traditional and digital political resources to support this action, including social media influencers. This policy demonstrates Wasko (2014) argument concerning the allocation of resources for and within capitalist actors, which resulted in marginalizing health issues as a necessary public interest.

Following Hardy (2014), it is apparent that Jokowi's strategy of risk communication is motivated by multiple political and economic factors. Analyzing several policies of COVID-19 at the two levels: presidential and ministerial decrees, it can be seen that all risk communication policies within the above laws are motivated to stabilize the economic climate, avoiding the ideal goal of governmental policy to prioritize public health protection.

The study shows that the role of the state in the national arena remains strong in protecting the sustainability of huge corporations instead of reallocating economic resources to the wider public. It confirms Karl Marx's notion of the dominance of state-capitalists over society (Obo \& Coker, 2014), both in the COVID-19 policy, orientation, and its practice.

The prioritization of the economy over health, for example, is evident in three areas: budget allocation, reluctance to impose a strict national lockdown, and selecting digital industries to provide social assistance.

The communication policy indicating the prioritization of economic stability is evident in the massive campaign of social distancing carried out in order to anticipate demands for a national lockdown. State funds for social assistance were unavailable, and thus largescale social restrictions were favored over lockdown. President Jokowi stressed that he had never considered a lockdown, and forbade regional governments from totally closing their territories. Jokowi asked people to "slow down", to work from home (WFH), study at home, and worship at home.

The real reason for Jokowi's reluctance to impose lockdown (as urged by social activists) was likely the shaky state of capital markets. Many Indonesians, particularly in the informal sector, survive on subsistence wages of $\$ 100$ 200 per month; if they were to lose that income due to lockdown, the effects would be hard to predict. Indonesian authorities, therefore, waged a public health war against COVID-19 while using limited financial resources to fight off a possible recession and liquidity crisis (Guild, 2020).

On March 5, 2020, Jakarta Governor Anies Baswedan proposed a lockdown to avoid the spread of the pandemic. A day later, he reduced the frequency and capacity of public transportation systems such as Transjakarta, Light Rapid Transit (LRT), and Mass Rapid Transit (MRT), resulting in long queues at stations and political controversy on social media. When acting Minister of Transportation Luhut Binsar Pandjaitan rejected this local policy, the central government asserted its priorities (Tirto.id, 2020 April 1). The Jokowi regime thus prioritized its economic agenda above the health and welfare of the public. This situation can be understood within the context of the government's prioritization of accelerating physical infrastructure development and alliance with large-scale, digital technologybased business groups. This orientation is also reflected in the involvement of top ministers and special staff and has affected the creation of public communication strategies. 
The most controversial policy of the Jokowi government was to use digital technology-based industries that existed before the pandemic as a partner for disseminating ideas, conditioning the public mind, and social assistance. For example, digital payment companies such as GoPay have vigorously sought to increase the effectiveness of social assistance (Kania, 2020). Similar to how multinational social media giants such as Facebook and YouTube profited from the chaotic political communication during Indonesia's 2014 and 2019 general elections, these companies have employed their close alliances with political leaders to profit from the COVID-19 crisis.

Social assistance, particularly the preemployment card (kartu pra kerja) program, has facilitated two interests: political cronyism and industrial survival. After registration was first opened on April 11, 2020, the program - and its main goal of reducing unemployment-has been accelerated to mitigate the economicimpact of the COVID-19 pandemic. The publication of the pre-employment card program may also be seen as a form of communication that supports the interests of digital corporations, who are generally supporters of the Jokowi regime. However, this policy contradicts the official 2020 Work Plan document, which requires a professional institution to manage the program (Kania, 2020). Likewise, management of the program by officials from the Kantor Kepala Staff President (Presidential Staff Office/KSP) violates the requirement that independent experts be involved.

The appointment of Ruang guru-a startup company owned by Belva Devara (one of Jokowi's Special Staff members)-as a training partner for the pre-employment card program was controversial. Rather than clarify its bidding process, through which Rp 5.6 trillion of the $\mathrm{Rp} 20$ trillion budget went to digital training institutions, Coordinating Minister for the Economy Airlangga Hartarto defended Ruangguru's inclusion in a series of media statements (Detik.com, 2020 April 17). Ultimately, this was perceived as political cronyism, reflecting similar practices in the New Order; as stated in Kunio's "The Rise of Ersatz Capitalism in South-East Asia" (Kunio, 1988), entrepreneurial projects during the New Order regime accessed the state budget through special links with President Soeharto and his family. Such practices have endured, with Ruangguru and other digital companies taking economic advantage of the pandemic and enjoying windfalls as online learning and other activities have become popular.

The climax of the Jokowi's government's prioritization of post-COVID-19 economic stability was its decision to expedite the passage of two unpopular bills. One was the revised criminal code, which faced deadly demonstrations in response, and the other was the labor deregulation bill (Mahy, 2020). It confirms what Sparkes et al. (2019) argue that the ruling government sought to continue to secure infrastructure development and promote macro-economic stability rather than ensure citizens' welfare during the pandemic.

This study informs that COVID-19 pandemic in Indonesia has sparked a political feud between incumbents' supporters and opponents. In the United States, the citizens' political orientation has determined how they understand and respond to the public statements of political authorities (Grossman et al., 2020), while in Indonesia, a discursive war about COVID-19 has been waged between the supporters of Joko Widodo and Jakarta Governor Anies Baswedan. Many political administrations and their supporters in both states have used the pandemic as a political proxy. For instance, most of the public discourse on the coronavirus in the US focuses, for understandable reasons, on just how disheartening this is, and what it tells the public about the present state of the US political polarization: Republicans vs. Democrats. 
The same situation is also happening in Indonesian politics: Hermawan, (2020) found, there has been an attempt to portray those who back the idea of imposing a lockdown to counter COVID-19 pandemic as kadrun (desert lizards), a derogatory term used by Jokowi's supporters to describe detractors, those openly rooting for Jakarta Governor Anies Baswedan as the next president. Even though Baswedan's Islamist allies have urged their followers to cancel religious gatherings and postpone travel, the president's supporters have accused them of playing politics. In fact, the central government has steadily undermined Baswedan's efforts to manage the crisis. Even though Jakarta is the nation's coronavirus epicenter, the requests to impose strict social distancing measures were repeatedly denied, citing potential economic consequences. Even after the declaration of a nationwide health emergency, his request was held up further by the health minister. Only after massive protests and days of haggling over data was this request approved.

It is important to note that social media buzzers play a key role in garnering support or waging a discourse war on social media (Howard \& Bradshaw, 2019) with COVID-19 as a political proxy. Controversy over buzzers arose in February 2020, when Jokowi announced his idea to involve influencers to spur tourist visits. Minister for Tourism Wishnutama (Tempo. co, 2020 February 26), announced a plan to disburse $\mathrm{Rp} 72$ billion in funds to the media and digital influencers in return for promoting tourism. He explained that this money was part of a Rp 298.5 billion stimulus package intended to attract foreign tourists, one that also included Rp 98.5 billion for airfare subsidies and Rp 103 billion for commercial advertising.

From a political perspective, the involvement of political buzzers to advance government agendas may be attributed to a general sense of political and economic insecurity. Willett (2001) illustrates that every country desires a sense of security, one that covers more than traditional security (such as national defense). The involvement of buzzers as communicators during the pandemic represents the desire to avoid potential political instability and insecurity by advocating the central government's programs over those of local governments and political opposition groups.

Finally, the predominance of former military elites in steering COVID-19 communication indicates that a security approach to communication drove its fabrication of pandemic data (Jeffrey, 2020). The author observed that all of the persons tasked with coordinating Indonesia's crisis response are retired army officers, including Doni Munardo (the head of the disaster management task force), Achmad Yurianto (the national spokesman on the coronavirus crisis), Terawan Agus Putranto (the health minister), as well as the Minister of Religion, the Coordinating Minister of Maritime and Investment Affairs, the Minister of Defense, and the Chief of Staff. Jokowi's government has the highest concentration of military personnel of any cabinet since the fall of Suharto's military dictatorship in 1998, and as such it is not surprising that a security approach has dominated his response to COVID-19.

This security and/or political stability approach informed the regime's initial response to the COVID-19 outbreak. In March 2020, Jokowi considered responding to the health crisis by declaring a civil emergency (darurat sipil), which is legally reserved for fighting rebellions and civil war. Although such a declaration promoted the imposition of large-scale social restrictions, it faced protests from various elements of civil society, mainly because the policy discourse was considered irrelevant and perceived as having the potential to violate citizens' civil and political rights.

Overall, the Jokowi government's communication policies during the pandemic can be understood through the concept of 
knowledge and power, both of which are exclusively his domain. Harold Adams Innis, a Canadian political economist, coined the term 'knowledge and information mastery' to refer to situations where governments, as the sole and strongest actors in the COVID-19 pandemic and other crises, monopolize knowledge, data and make information exclusive to certain groups in order to maintain the stability and/ or instability of political power (Comor, 2001).

\section{Conclusion}

This paper overall shows that Jokowi's government positioned COVID-19 as a 'political event' (Olson \& Gawronski, 2010), prioritizing economic stability rather than managing public health crises. The study has advanced previous studies (Wijayanto, 2020) on blunders in COVID-19 communication between February and May 2020, finding that market-driven communication practices have stymied the need to protect public health. It also confirms Karl Marx's theory of 'class-state' domination (Obo \& Coker, 2014) over ordinary society. The study shows strong state intervention through the production of regulatory capitalism (LeviFaur, 2009) with the interests of market actors being prioritized over those of ordinary people in COVID-19 prevention.

This paper highlights the political and politicized discourses surrounding COVID-19. It finds that two factors-promarket/capitalism communication policies and manufactured-politicized COVID-19 pandemic - have been prominent. Although these communication practices are primarily used for packaging issues in such a manner that secret interests are concealed, this paper has uncovered them. The manipulation of the pandemic risks has led to increased fatalities and pathogenic exposure.

This paper approves that political and economic concerns have impacted the communication goals of political authorities, including Indonesia. It confirms Bland, (2019) claim that Jokowi's actions remain motivated by promoting economic progress, and this has caused blunders in communication and recovery programs. The government's risk communication policies and public exposure have been influenced by the pragmatic narratives of political and economic stability promoted by political agencies and corporate interest groups. In the global arena, these strategic narratives are at odds with the messaging recommended by the World Health Organization and other leading public health authorities, creating a conflict of interest that has a direct impact on public message consumption and public health needs.

This paper finally demonstrates that, in this pandemic era, the Jokowi government has continued using the same strategies as the Suharto regime and prioritized economic growth over public welfare. Although Jokowi has often been depicted as a "reformer", and has himself played up this idea, he values political stability over risk-taking. He has always taken a cautious approach to advocate for change, even in the economic sphere that is most important to him. Jokowi's formative years were spent under the autocratic rule of Suharto, who had also prioritized political stability and economic growth over public transparency and accountability.

\section{References}

BBC. (2020, May 12). Perppu penanganan virus corona: "Imunitas absolut penguasa" gunakan uang negara Rp.405 triliun tanpa bisa dituntut hukum, kata pegiat anti korupsi. BBC Indonesia. Retrieved from https://www.bbc.com/indonesia/ indonesia-52616906

Bland, B. (2019). How president Joko Widodo is eroding Indonesia's democracy. Www. Ispionline.It. Retrieved from https:// www.ispionline.it/en/pubblicazione/ how-president-joko-widodo-erodingindonesias-democracy-24587 
Campos, P. A., \& Reich, M. R. (2019). Political analysis for health policy implementation. Health Systems \& Reform, 5(3), 224-235. https://doi.org/10.1080/23288604.2019.1 625251

Cherkaoui, M. (2020). The shifting geopolitics of coronavirus and the demise of neoliberalism. Studies.Aljazeera.Net/. Retrieved from https://studies.aljazeera.net/en/reports/ shifting-geopolitics-coronavirus-anddemise-neoliberalism---part-2

Comor, E. (2001). Harold innis and "The Bias Of Communication." Information, Communication \& Society, 4(2), 274-294. https://doi.org/10.1080/713768518

Coombs, W. T. (2008). Crisis communication. In Wolfgang Donsbach (Ed.) International Encyclopedia of Communication (pp. 10541060). Blackwell.

Denzin, N. K., \& Lincoln, Y. S. (1994). Entering the field of qualitative research. Thousand Oaks: Sage.

Detik.com. (2020, April 17). Blak Blakan Kartu Pra Kerja dan Nepotisme dengan Pak Menteri. Finance.Detik.Com. Retrieved from https://finance.detik.com/berita-ekonomibisnis/d-4980400/blak-blakan-kartu-prakerja-dan-nepotisme-dengan-pak-menteri

Dickmann, P., Biedenkopf, N., Keeping, S., Eickmann, M., \& Becker, S. (2014). Risk Communication and Crisis Communication in Infectious Disease Outbreaks in Germany: What Is Being Done, and What Needs to be Done. Disaster Medicine and Public Health Preparedness, 8(3), 206-211. https://doi. org/10.1017/dmp.2014.36

Fuchs, C., \& Mosco, V. (2016). Introduction: Marx is back - the importance of marxist theory and research for critical communication studies today. In Marx and the Political Economy of Media. Brill.

Gerstenfeld, M. (2020). Political leadership during the coronavirus crisis. Besacenter.Org. Retrieved from https://besacenter.org/ perspectives-papers/political-leadershipduring-the-coronavirus-crisis/

Grossman, G., Kim, S., Rexer, J. M., \& Thirumurthy, H. (2020). Political partisanship influences behavioral responses to governors' recommendations for COVID-19 prevention in the United States. Proceedings of the National Academy of Sciences, 117(39), 24144-24153. https:// doi.org/10.1073/pnas.2007835117

Guild, J. (2020). The economic consequences of coronavirus in Indonesia. Thediplomat. Com. Retrieved from https://thediplomat. com/2020/03/the-economic-consequencesof-coronavirus-in-indonesia/

Hardy, J. (2014). Critical political economy of the media: An introduction. Routledge.

Herman, E. S., \& Chomsky, N. (2000). Manufacturing consent: The political economy of the mass media. Pantheon.

Hermawan, A. (2020). Politics of pandemics: How online "buzzers" infect Indonesia's democracy, jeopardize its citizens. The Jakarta Post. Retrieved from https://www. thejakartapost.com/academia/2020/03/21/ covid-19-doesnt-care-about-politicshow-online-buzzers-infect-indonesiasdemocracy.html.

Howard, P. N., \& Bradshaw, S. (2019). The global disinformation order: 2019 global inventory of organized social media manipulation. Oxford Internet Institute.

Hsu, Y.-C., Chen, Y.-L., Wei, H.-N., Yang, Y.-W., \& Chen, Y.-H. (2017). Risk and outbreak communication: Lessons from Taiwan's experiences in the Post-SARS era. Health Security, 15(2), 165-169. https:// doi.org/10.1089/hs.2016.0111

J, I., J, S., MM, B., J, N.-C., C, O.-O., \& GuillénGrima F. (2013). A literature review on effective risk communication for the prevention and control of communicable diseases in Europe. ECDC. Retrieved from https:// www.ecdc.europa.eu/sites/default/files/ media/en/publications/Publications/risk- 
communication-literary-review-jan-2013. pdf

Jakarta.Post. (2020, March 14). COVID-19: WHO urges Jokowi to declare national emergency. Www. Thejakartapost. Com. Retrieved from https://www. thejakartapost.com/news/2020/03/14/ covid-19-who-urges-jokowi-to-declarenational-emergency.html

Jeffrey, S. (2020). Coronavirus blunders in Indonesia turn crisis into catastrophe. Carnegieendowment.Org. Retrieved from https://carnegieendowment.org/2020/04/29/ coronavirus-blunders-in-indonesia-turncrisis-into-catastrophe-pub-81684

Kania, R. (2020). Kartu prakerja: Ketika kelompok kepentingan terlibat dalam 'Solusi' krisis COVID-19. Theconversation.Com. Retrieved from https://theconversation. $\mathrm{com} /$ kartu-prakerja-ketika-kelompokkepentingan-terlibat-dalam-solusi-krisiscovid-19-137021

Kompas.com. (2020a, March 13). Jokowi akui pemerintah rahasiakan sejumlah informasi soal corona. Nasional.Kompas. Com. Retrieved from https://nasional. kompas.com/read/2020/03/13/16163481/ jokowi-akui-pemerintah-rahasiakansejumlah-informasi-soal-corona $\% 0 \mathrm{~A}$

Kompas.com. (2020b, April 11). 32.000 orang Jakarta diperkirakan positif Covid-19, PSBB bisa tekan infeksi corona. Www.Kompas.Com. Retrieved from https://www.kompas.com/sains/ $\mathrm{read} / 2020 / 04 / 11 / 164500823 / 32.000-$ orangjakarta-diperkirakan-positif-covid-19psbb-bisa-tekan-infeksi

Kunio, Y. (1988). The Rise of Ersatz Capitalism in South-East Asia. Oxford University Press.

Levi-Faur, D. (2009). Regulatory capitalism and the reassertion of the public interest. Policy and Society, 27(3), 181-191. https:// doi.org/10.1016/j.polsoc.2008.10.002

Mahy, P. (2020). Covid-19 and labour law: Indonesia. Italian Labour Law E-Journal,
13(1). https://illej.unibo.it/article/ view/10937

McChesney, R. W. (2012). The political economy of communication. In The International Encyclopedia of Media Studies. Blackwell Publishing Ltd. https://doi. org/10.1002/9781444361506.wbiems031

McLean, H., \& Ewar, J. (2015). Hindrance or help? A model for the involvement of politicians in communicating with publics during disasters. International Journal of Mass Emergencies and Disasters, 33(2), 228-252. Retrieved from http://www. ijmed.org/articles/679/

Menon, K. U., \& Goh, K. T. (2005). Transparency and trust: Risk communications and the Singapore experience in managing SARS. Journal of Communication Management, 9(4), 375-383. https://doi. org/10.1108/13632540510621614

Michelle Driedger, S., Maier, R., \& Jardine, C. (2018). 'Damned if you do, and damned if you don't': Communicating about uncertainty and evolving science during the H1N1 influenza pandemic. Journal of Risk Research, 1-19. https://doi.org/10.108 0/13669877.2018.1459793

Mosco, V. (2004). The Political Economy of Communication. SAGE Publications.

Mosco, V. (2009). The Political Economy of Communication. SAGE Publications.

Obo, U. B., \& Coker, M. A. (2014). The marxist theory of the state: An introductory guide. Mediterranean Journal of Social Sciences. https://doi.org/10.5901/mjss.2014. v5n4p527

Olson, R. S., \& Gawronski, V. T. (2010). From disaster event to political crisis: A " $5 \mathrm{C}+\mathrm{A}$ " framework for analysis. International Studies Perspectives, 11(3), 205-221. https:// doi.org/10.1111/j.1528-3585.2010.00404.x

Quinn, P. (2018). Crisis communication in public health emergencies: The limits of 'Legal Control' and the risks for harmful outcomes in a digital age. Life Sciences, 
Society and Policy, 14(1), 4. https://doi. org/10.1186/s40504-018-0067-0

Reuters. (2020, April 28). Exclusive: More than 2,200 Indonesians have died with coronavirus symptoms, data shows. Www.Reuters.Com. Retrieved from https:// www.reuters.com/article/us-healthcoronavirus-indonesia-casualti/exclusivemore-than-2200-indonesians-have-diedwith-coronavirus-symptoms-data-showsidUSKCN22A04N.

Rizky, A. (2020). Menakar isi dompet pemerintah. Tajuk.Co. Retrieved from https://tajuk.co/ news/menakar-isi-dompet-pemerintah

Seneviratne, K., Baldry, D., \& Pathirage, C. (2010). Disaster knowledge factors in managing disasters successfully. International Journal of Strategic Property Management, 14(4), 376-390. https://doi. org/10.3846/ijspm.2010.28

Sparkes, S. P., Bump, J. B., Özçelik, E. A., Kutzin, J., \& Reich, M. R. (2019). Political economy analysis for health financing reform. Health Systems \& Reform, 5(3), 183-194. https://doi.org/10.1080/2328860 4.2019.1633874

Tempo.co. (2020, February 28). Promosi Wisata Rp. 72 M, Wishnutama Sebut Sewa Influencer Asing. Nasional.Tempo.Co. Retrieved from https://nasional.tempo.co/ $\mathrm{read} / 1312301 /$ promosi-wisata-rp-72-mwishnutama-sebut-sewa-influencer-asing

Tirto.id. (2020, April 1). Ramai-Ramai Istana Jegal Kebijakan Anies Hadapi COVID-19. Tirto. Id. Retrieved from https://tirto.id/eJZB.

Vaughan, E., \& Tinker, T. (2009). Effective health risk communication about pandemic influenza for vulnerable populations. American Journal of Public Health, 99(S2), S324-S332. https://doi.org/10.2105/ AJPH.2009.162537
Wasko, J. (2014). The study of the political economy of the media in the twenty-first century. International Journal of Media $\mathcal{E}$ Cultural Politics, 10(3), 259-271. https:// doi.org/10.1386/macp.10.3.259_1

Wijayanto. (2020, July 22). 37 Pernyataan Blunder Pemerintah terkait Covid-19. Nasional.Kompas.Com. Retrieved from https://nasional.kompas.com/ $\mathrm{read} / 2020 / 04 / 06 / 17522121 / 1 \mathrm{p} 3$ es-catatada-37-pernyataan-blunder-pemerintahsoal-covid-19? page $=2$

Willett, S. (2001). Insecurity, conflict and the new global disorder. IDS Bulletin, 32(2), 35-47. https://doi.org/10.1111/j.1759-5436.2001. mp32002004.x

Winanti, P. S., \& Mas'udi, W. (2020). Policy brief: Problem infodemik dalam merespon pandemi Covid-19. Fisipol UGM. Retrieved from https://fisipol.ugm.ac.id/wp-content/ uploads/sites/1056/2020/04/Policy-BriefProblem-Infodemic-dalam-MeresponPandemi-COVID-19.pdf

Winseck, D. (2016). Reconstructing the political economy of communication for the digital media age. The Political Economy of Communication, 4(2), 73-114. https:// www.polecom.org/index.php/polecom/ article/view/72

Worldometer. (2020). COVID-19 Coronavirus Pandemic. https://www.worldometers. info/coronavirus/\#countries $\% 0 \mathrm{~A}$

Xiang, D., Kontos, C., Veloudaki, A., Karnaki, P., Baka, A., Lino, A., \& Robertso, T. V. (2017). Epidemics and pandemics: The response of society. Rome: Zadig S.r.L., 7, 2532-3784. http://www.asset-scienceinsociety.eu/ outputs/epidemics-and-pandemicsresponse-society-asset-paper-seriesissn-2532-3784/paper-series-7 